\title{
Do Littoral Macrophytes Influence Crustacean Zooplankton Distribution?
}

\author{
A. M. Geraldes ${ }^{1} \&$ M. J. Boavida ${ }^{2 *}$ \\ ${ }^{1}$ CIMO, Escola Superior Agrária de Bragança, Campus de Santa Apolónia 5301-885 Bragança, Portugal \\ (geraldes@ipb.pt) \\ ${ }^{2}$ Centro de Biologia Ambiental, Departamento de Biologia Animal, Faculdade de Ciências da Universidade \\ de Lisboa, Campo Grande C8, 1749-016 Lisboa, Portugal (mjboavida@fc.ul.pt) \\ * Author for correspondence
}

\begin{abstract}
In a meso-eutrophic reservoir, cladoceran and copepod assemblages were characterised in two sampling sites: One located in the pelagic zone (site 1) and the other in the shallow littoral zone (site 2), the latter colonised by emergent macrophytes. Samples were collected biweekly from June to July 2001 and from May to July 2002 at the two sites. At site 1, crustacean zooplankton samples were obtained by vertical hauls using a Wisconsin type net of $64 \mathrm{~mm}$ mesh size. At site 2 several random samples were obtained using a van Dorn bottle. Those samples were pooled together and the total sample was sieved through a $64 \mathrm{~mm}$ mesh size. Macrophyte relative abundance for each species was visually estimated. Macrophyte community was composed of Glyceria declinata, Eleocharis palustris and Carex sp. A Mann-Whitney U-test was carried out to test for statistically significant differences between sites, for environmental parameters and crustacean zooplankton species densities. Alona rectangula, Alona costata, Alona quadrangularis and Chydorus sphaericus were only found in littoral samples. Daphnia longispina, Daphnia pulex, Ceriodaphnia pulchella, Bosmina longirostris, Diaphanosoma brachyurum, Copidodiaptomus numidicus, and Acanthocyclops robustus were found at both sites. However, Daphnia and Bosmina densities did not differ significantly between the pelagic and littoral sites. Ceriodaphnia, Diaphanosoma, and C. numidicus densities were significantly higher in the pelagic site, whereas $A$. robustus densities showed the opposite pattern.
\end{abstract}

Key-words: Zooplankton, Cladocera, Copepoda, reservoir, macrophytes, pelagic zone, littoral zone

\section{RESUMEN}

En un embalse meso-eutrofico las comunidades de cladóceros y copépodos fueron caracterizadas en dos estaciones de muestreo. Una localizada en la zona pelágica (estación 1) y la otra en la zona litoral (estación 2). Esta última está colonizada por macrofitos emergidos. Los muestreos fueron efectuados quincenalmente de Junio a Julio de 2001 y de Mayo a Julio de 2002 en las dos estaciones. En la estación 1 los muestreos de crustáceos del zooplancton se obtuvieron mediante arrastre vertical utilizando una red tipo Wisconsin de $64 \mathrm{~mm}$ de poro. En la estación 2 se realizaron varias muestras aleatorias con una botella tipo van Dorn. Las muestras obtenidas en la estación 2 se juntaron y la muestra total resultante fue filtrada por una red de $64 \mathrm{~mm}$ de poro. La abundancia relativa de cada una de las especies de macrófitos fue estimada visualmente. La comunidad de macrófitos está constituida por Glyceria declinata, Eleocharis palustris y Carex sp. Fue realizado el test de U de Mann-Whitney para detectar las diferencias estadísticamente significativas entre las dos estaciones, para los parámetros ambientales y para las densidades de los crustáceos del zooplancton. Alona rectangula, Alona costata, Alona quadrangularis $y$ Chydorus sphaericus se han observado únicamente en los muestreos obtenidos en el litoral. Daphnia longispina, Daphnia pulex, Ceriodaphnia pulchella, Bosmina longirostris, Diaphanosoma brachyurum, Copidodiaptomus numidicus $y$ Acanthocyclops robustus se han encontrado en ambas estaciones, no obstante las densidades de Daphnia y Bosmina no presentan diferencias estadísticamente significativas entre la zona pelágica y la litoral. Las densidades de Ceriodaphnia, Diaphanosoma y C. numidicus fueran significativamente más elevadas en la zona pelágica, mientras que la densidad de A. robustus presentó un patrón opuesto.

Palabras clave: Zooplancton, Cladocera, Copepoda, embalse, macrófitos, zona pelágica, zona litoral 


\section{INTRODUCTION}

In the littoral zone of lakes, macrophytes provide a diverse array of surfaces for colonisation, feeding and refuge, not only for plant-associated microcrustaceans but also for pelagic species (e.g. Beklioglu \& Moss, 1996; Gasith \& Hoyer, 1998; Jeppesen et al., 1998; Kairesalo et al., 1998; Bergström et al., 2000; Nurminen \& Horppila, 2002). According to Jeppesen et al.(1998) if plant beds are present, cladocerans such as Ceriodaphnia spp., Diaphanosoma brachyurum and cyclopoid copepods are often more abundant in the littoral zone than in the open waters, whereas calanoid copepod densities show the opposite pattern. Despite the abundance of literature concerning natural lakes, studies investigating the importance of macrophyte communities in reservoirs seem to be non-existent. In fact, the littoral zone of the reservoirs is strongly conditioned by water level fluctuations of large amplitude. As a consequence of those variations, macrophyte communities do not exist or are restricted in space and time (e.g. Wetzel, 1990; 2001).

Azibo Reservoir is located in the Portuguese part of the Douro River watershed and is an exception to this pattern. As water use is not very intense, annual water level fluctuations are of small magnitude, ranging between 1.5 and 2 $\mathrm{m}$. This fact allows for the existence of emergent macrophytes in the littoral shallow areas of the reservoir. Macrophyte growing season runs from May to July. At the end of July water level decreases, macrophyte growth areas dry and remain so until the first autumn rains. This research represents a preliminary insight into the

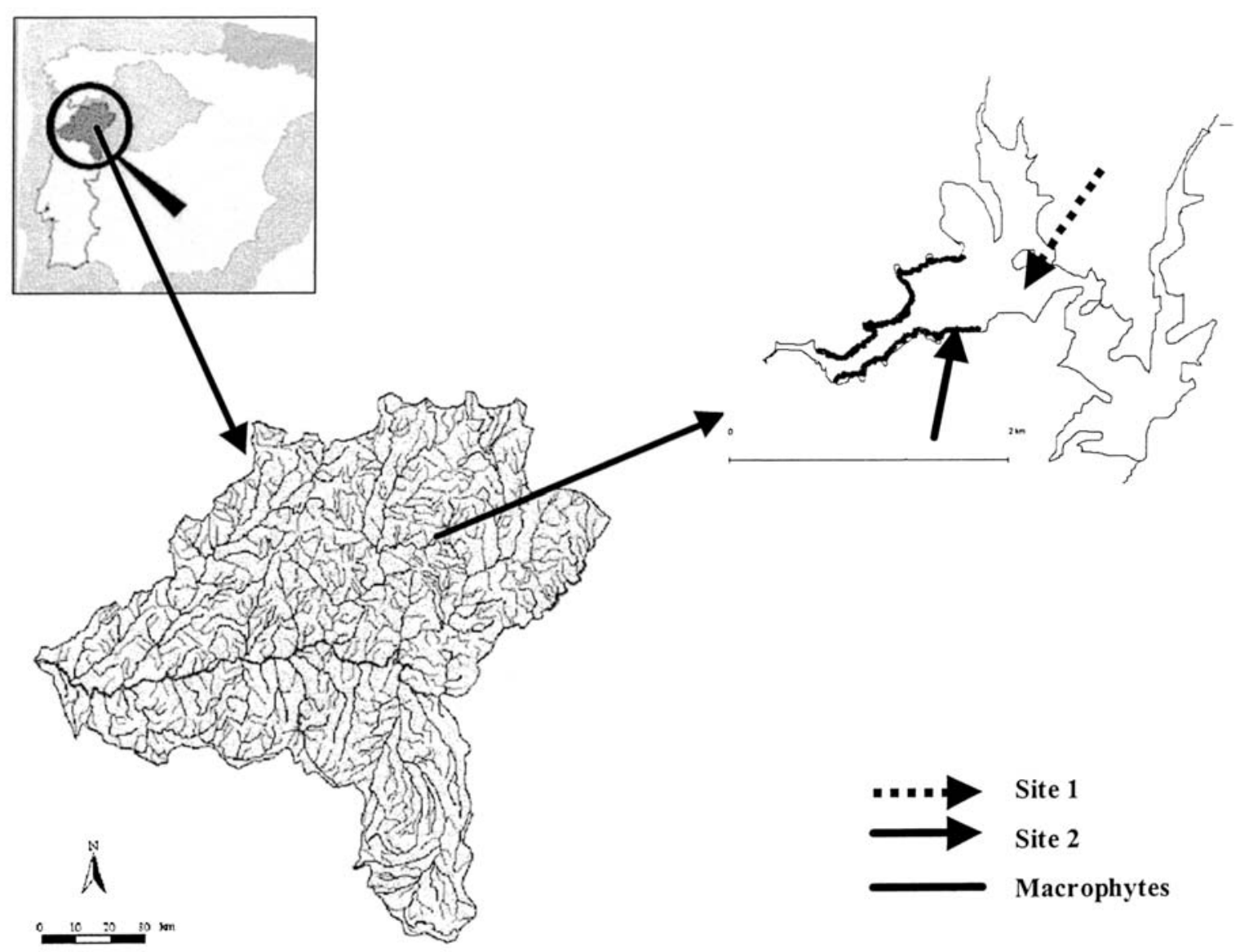

Figure 1- Azibo Reservoir with indication of sampling sites. Embalse de Azibo y localización de las estaciones de muestreo. 
potential role of those temporary macrophyte communities in structuring microcrustacean assemblages, which dominated zooplankton in this reservoir (Geraldes \& Boavida, 2004). Thus, the objective of this study was to assess whether cladocerans and copepods found in this reservoir were preferably found in shallow littoral areas with macrophytes rather than in pelagic waters. To achieve this objective crustacean zooplankton assemblages from both the pelagic zone and the littoral zone colonised by macrophytes were characterised and compared.

\section{STUDY AREA}

Azibo Reservoir is located in the Portuguese part of the Douro River watershed. The reservoir's total capacity is $54470 \times 10^{3} \mathrm{~m}^{3}$ and it covers an area of 410 ha. Maximum depth is about $30 \mathrm{~m}$, while mean depth is $13.2 \mathrm{~m}$. This reservoir was filled for the first time in 1982. The direct influence of human activities on the impoundment is more accentuated during summer, when the reservoir and surroundings are used for recreational activities. Other activities found year round in the reservoir watershed are farming and grazing. Water is also used for urban supply and irrigation, but these are not significant and water level fluctuations are not very accentuated, ranging between 1.5 and $2 \mathrm{~m}$. Consequently, shallow areas of the reservoir are colonised by emergent macrophytes (Fig.1). Before pike (Esox lucius) introduction in the 1990 's, fish community was mainly composed of cyprinids. The relative abundance of cyprinid fish significantly decreased upon pike introduction (Table 1). In the region where Azibo is located, the climate is continental, with warm, dry summers and long, cold winters. However, because of the influence of Mediterranean climate in the remaining Iberian Peninsula, precipitation occurs mainly in autumn and winter with wet winters usually alternating with dry ones. Total annual precipitation varies between 800 and $1000 \mathrm{~mm}$ and mean annual air temperature ranges between $12.5{ }^{\circ} \mathrm{C}$ and $14{ }^{\circ} \mathrm{C}$. Thermal stratification occurs from June to October. The reservoir was classified as meso-eutrophic (Geraldes \& Boavida, 2003).

Table 1- Relative abundance and number of fish captured (in parenthesis) in June and August 1987/1988 before pike introduction (Formigo, 1990), and during the same period in 1994 after pike introduction (Albuquerque, unpubl. bachelor thesis)). Abundancia relativa y número de peces muestreados (entre paréntesis) en Junio y Agosto 1987/1988 antes de la introducción de lucio (Formigo, 1990) y en lo mismo periodo en 1994, después de la introducción de esta especie (Albuquerque, tesis de grado)).

\begin{tabular}{lccc}
\hline & $\mathbf{1 9 8 7}$ & $\mathbf{1 9 8 8}$ & $\mathbf{1 9 9 4}$ \\
\hline Cyprinidae & & & \\
Chondrostoma duriensis & $70.09\left(164^{*}\right)$ & $80.85\left(460^{*}\right)$ & $6.97\left(9^{* *}\right)$ \\
Barbus bocagei & $18.79\left(44^{*}\right)$ & $15.11\left(86^{*}\right)$ & $11.62\left(15^{* *}\right)$ \\
$\begin{array}{l}\text { Cyprinus carpio } \\
\text { Carassius auratus }\end{array}$ & $10.26\left(24^{*}\right)$ & $3.51\left(20^{*}\right)$ & $25.60\left(33^{* *}\right)$ \\
Squalius carolitertii & - & - & $14.73\left(19^{* *}\right)$ \\
Salmonidae & $0.43\left(1^{*}\right)$ & $0.35\left(2^{*}\right)$ & $* * *$ \\
Salmo trutta & $0.43\left(1^{*}\right)$ & $0.18\left(1^{*}\right)$ & - \\
Centrarchidae & - & & $6.20\left(8^{* *}\right)$ \\
Micropterus salmoides & - & & $34.88\left(45^{* *}\right)$ \\
Esocidae & - & & \\
Esox lucius & & & \\
\hline
\end{tabular}

Catch effort unit * $=$ net $^{-1} \mathrm{Ih}^{-1} ; * *$ net $^{-1} 14 \mathrm{~h}^{-1}$;

***Recorded in pike guts (percentage occurrence of $7.14 ; \mathrm{n}=14$ guts) 


\section{METHODS}

Samples were collected biweekly from June to July 2001 and from May to July 2002 at two sampling stations (Fig. 1): One located at the pelagic zone of the reservoir (site 1) and the other located in a littoral shallow area covered by emergent macrophytes (site 2). Crustacean zooplankton samples were obtained at site 1 by taking two vertical hauls using a Wisconsin type net of $64 \mu \mathrm{m}$ mesh size. At site 2 (water depth 55 $60 \mathrm{~cm}$ ) several random samples were obtained using a van Dorn bottle (length $41 \mathrm{~cm}$, diameter $60 \mathrm{~mm}$ ) that was lowered to a few centimetres above the sediment surface. Those samples were pooled together and the total sample was sieved through a $64 \mu \mathrm{m}$ mesh size. Animals were anaesthetised with carbonated water and preserved in sugar-saturated formaldehyde (4\% final concentration). Depending on density, zooplankton were counted from sub samples of 5, 10, $20 \mathrm{ml}$, or from the total sample. Animals were identified to species level, according to Scourfield \& Harding (1966), and Dussart (1969). Macrophyte coverage was visually estimated at site 2. Water samples for soluble reactive phosphorus (SRP), total phosphorus (TP) and chlorophyll $a$ (CHL $a$ ) determination were obtained from the upper $30 \mathrm{~cm}$ of the water column at both sampling sites. SRP concentrations were measured using the method by Murphy \& Riley (1962), and TP was assessed after acid hydrolysis with persulfate for $60 \mathrm{~min}$ under high temperature and pressure (APHA 1989). CHL $a$ was obtained from 500 to $1000 \mathrm{ml}$ of sampled water filtered through a Whatman GF/A filter no more than $2 \mathrm{~h}$ after collection. Concentrations were determined with a spectrophotometer after overnight extraction in $90 \%$ acetone. Water temperature, dissolved oxygen, conductivity and $\mathrm{pH}$ were measured in situ with a 6820 YSI Multiparameter Water Quality Monitor.

A Mann-Whitney U-test was carried out to test for statistically significant differences, between sites, for environmental parameters and species densities. Statistical analyses were performed using SPSS 8.0.

\section{RESULTS}

No significant statistical differences were found between sampling sites for environmental variables (Table 2). In site 2 the emergent macrophyte community was composed of Glyceria declinata, covering $40 \%$ of the sampled area, Eleocharis palustris and Carex sp., covering each $30 \%$ of the sampled area.

Eleven crustacean zooplankton species were observed. Since no statistically significant interannual differences were found for species densities either in site 1 or in site 2, data from both years were pooled together (Table 3). Alona rectangula, Alona costata, Alona quadrangularis (for statistical analyses these species were grouped together as Alona spp. because of their ecological similarity) and Chydorus sphaericus were only found in site 2 . The other zooplanktonic crustaceans found in Azibo were the cladocerans Daphnia longispina, Daphnia pulex (for statistical analyses these species were grouped together as Daphnia spp. for the same reason stated for Alona), Ceriodaphnia pulchella, Bosmina longirostris, and Diaphanosoma brachyurum, plus the copepods Copidodiaptomus numidicus, and Acanthocyclops robustus.

Ceriodaphnia and Diaphanosoma densities were significantly higher in site 1 . Conversely, Daphnia and Bosmina densities did not exhibit significant differences between sites. C. numidi-

Table 2- Mean \pm SD values of the environmental variables, minimum-maximum range for $\mathrm{pH}$ and results of Mann-Whitney U-test. Media $\pm S D$ de los parámetros ambientales, mínimo-máximo $\mathrm{pH}$ y resultados del test de U de Mann-Whitney.

\begin{tabular}{lccc}
\hline & Site $\mathbf{1}$ & Site 2 & P \\
\hline TP $(\boldsymbol{\mu g} / \mathbf{l})$ & $60.0 \pm 6.3$ & $76.7 \pm 27.1$ & $\mathrm{NS}$ \\
SRP $(\boldsymbol{\mu g} / \mathbf{l})$ & $4.3 \pm 2.0$ & $9.9 \pm 7.7$ & $\mathrm{NS}$ \\
$\mathbf{C H L} \boldsymbol{a}(\boldsymbol{\mu l g} / \mathbf{l})$ & $0.8 \pm 0.6$ & $0.8 \pm 0.7$ & $\mathrm{NS}$ \\
Water temperature $\left({ }^{\circ} \mathbf{C}\right)$ & $20.3 \pm 3.0$ & $21.0 \pm 3.1$ & $\mathrm{NS}$ \\
Dissolved oxygen $(\mathbf{m g} / \mathbf{l})$ & $8.8 \pm 1.2$ & $8.0 \pm 1.3$ & $\mathrm{NS}$ \\
Conductivity $(\boldsymbol{\mu S} / \mathbf{c m})$ & $64.0 \pm 6.4$ & $64.0 \pm 6.4$ & $\mathrm{NS}$ \\
$\mathbf{p H}$ & $6.9-8.1$ & $7.2-8.1$ & $\mathrm{NS}$ \\
\hline
\end{tabular}

$* \mathrm{P}<0.05 ; *$ P $<0.01 ; \mathrm{NS}$ : not significant 
Table 3- Mean \pm SD species densities (ind $/ \mathrm{m}^{3}$ ), and results of Mann-Whitney U-test. Media \pm SD de densidades de las especies presentes (ind $/ \mathrm{m}^{3}$ ) y resultados del test de $U$ de Mann-Whitney.

\begin{tabular}{lccc}
\hline & Site $\mathbf{1}$ & Site 2 & P \\
\hline Cladocera & & & $* *$ \\
Alona spp. & 0.0 & $4863.9 \pm 8168.2$ & NS \\
Bosmina longirostris & $104.6 \pm 184.7$ & $44.5 \pm 51.3$ & $*$ \\
Ceriodaphnia pulchella & $1161.8 \pm 1239.2$ & $203.2 \pm 300.5$ & $* *$ \\
Chydorus sphaericus & 0.0 & $158.7 \pm 196.4$ & NS \\
Daphnia spp. & $595.7 \pm 610.8$ & $22.2 \pm 34.0$ & $*$ \\
Diaphanosoma brachyurum & $1105.0 \pm 1916.2$ & $1000.0 \pm 990.2$ & $*$ \\
Copepoda & $166.0 \pm 127.3$ & $1847.6 \pm 2210.4$ & $*$ \\
Acanthocyclops robustus & $6361.6 \pm 3472.0$ & & \\
\hline
\end{tabular}

$* \mathrm{P}<0.05 ; * * \mathrm{P}<0.01 ; \mathrm{NS}:$ not significant

cus densities were significantly higher in site 1 , whereas $A$. robustus densities were significantly higher in site 2.

\section{DISCUSSION}

All taxa were found in both sampling sites, except Alona spp. and Chydorus sphaericus, which were only found in the littoral zone. These species are typically associated with macrophyte communities (Scourfield \& Harding, 1966). Dapnhia and Bosmina seemed to be as well widespread among macrophytes as in the pelagic zone, a similar pattern was also observed by Jeppesen et al. (1998). Conversely, Ceriodaphnia, Diaphanosoma and C. numidicus exhibited a clear preference for the pelagic zone; which might suggest a "shore avoidance" behaviour (Gliwicz \& Rykowska, 1992). According to these authors some species tend to avoid near-shore areas because there they are more vulnerable to young fish predation. In Azibo, fish were dominated by cyprinids during the 1980's (Formigo, 1990). Although cyprinid fish are not strictly planktivorous, they can have some impact on cladoceran and copepod assemblages (Winfield \& Towsend, 1992; Visman et al., 1994). In fact, cyprinids start feeding on zooplankton shortly after hatching and continue feeding mainly on this food item until they are around $15 \mathrm{~cm}$ long
(Lammens \& Hoogenboezem, 1992). However, in Azibo their impact on cladoceran and copepod assemblages might have been minimised, because of the introduction of pike in the reservoir in the 1990's. This fish caused an accentuated decrease in the resident cyprinid relative abundance (Table 1). Nowadays, according to angler information, pike is the dominant fish species in Azibo. After absorbing the yolk sac, juvenile pike feed on Daphnia and copepods during a few weeks, before they are able to feed on macroinvertebrates (Hunt \& Carbine, 1951). In fact, at the beginning of June, young fish shoals were observed near the shore in site 2 (Geraldes, pers. obs.). Thus, juvenile pike might have some temporary impact on cladoceran and copepod assemblages. Daphnia is one of the most important "targets" for fish predation (Gliwicz \& Rykowska, 1992; Winfield \& Towsend, 1992; Visman et al., 1994; Lampert \& Sommer, 1997; Lauridsen et al., 2001). However, Daphnia was abundant only during the winter and early spring months, being replaced afterwards by Ceriodaphnia, when temperature increased (Geraldes \& Boavida, 2004). Therefore, in this reservoir, Daphnia was not an important "target" for young pike, because this cladoceran and the young pike of the year did not coexist. The most important "targets" might have been Ceriodaphnia and Diaphanosoma, whose densities were high when young fish shoals were first noticed. 
Thus, the higher densities found in the pelagic zone might have been evidence of shore avoidance behaviour, as a strategy to avoid young fish predation. In fact, it is plausible to think that in the pelagic zone predation pressure was lower, since the occurrence of Chaoborus larvae was not detected there, and the abundance of adult cyprinids was very low. C. numidicus and $A$. robustus densities followed the same pattern as that described by Jeppesen et al. (1998). According to these authors calanoid copepods were always more abundant in the pelagic zone, whereas cyclopoid copepods densities followed the opposite pattern. According to Caramujo et al. (1997) C. numidicus youngest stages are a potential prey for $A$. robustus. Thus, higher abundance of $C$. numidicus in the pelagic zone can be regarded as a predation avoiding strategy. However, according to Wickham (1995) since cyclopoid copepods select smaller over large prey items, ciliates are potentially the preferred prey. Higher densities of ciliates and small cladocerans (e.g. Alona and Chydorus) found in littoral areas with macrophytes as compared to open water (Jeppesen et al., 1998; Wetzel, 2001), and the fact that copepods are less impacted than large cladocerans by young fish predation (Visman et al., 1994) might explain the clear shore preference behaviour exhibited by A. robustus in Azibo Reservoir. Here A. robustus would have the preferred prey (ciliates, smaller than young $C$. numidicus) and would be protected against predation as well (fish preferentially select cladocerans).

Except for plant-associated species and $A$. robustus, the macrophyte zone seemed not to be important either as a refuge or as a feeding habitat for crustacean zooplankton in Azibo Reservoir. However, further research is needed to elucidate: (1) daily variation on species horizontal distribution; (2) the actual impact of juvenile fish predation on crustacean zooplankton assemblages; (3) the importance of macrophytes as a refuge for young fish; and (4) the interactions between A. robustus and plant-associated microcrustaceans and ciliates. Clarification of the above mentioned items would constitute an important source of information to understand the ecological role of emergent macrophytes and to implement correct management practices leading to preservation of plant communities and water quality. This preliminary investigation constitutes the starting point for the research suggested above, and therefore it is worth to report it for its heuristic value.

\section{AKNOWLEDGMENTS}

This study was supported by Fundação para a Ciência e a Tecnologia, Portugal (Project Praxis $\mathrm{XXI} / \mathrm{C} / \mathrm{BIA} / 11012 / 98$ ) and a doctoral fellowship awarded to AMG (4/5.3/PRODEP/2000) for part of the study. Assistance of A. Ribeiro, A. Teixeira, N. Marcos, A. Saraiva, S. Branco and A. Costa in field work is appreciated. M. J. Caramujo kindly identified the copepods. So did N. Marcos for macrophytes. J. Sampaio provided local angler information.

\section{REFERENCES}

APHA 1989. Standard Methods for the Examination of Water and Wastewater, 17th ed. Washington: American Public Health Association.

BEKLIOGLU, M. \& B. MOSS. 1996. Mesocosm experiments on the interaction of sediment influence, fish predation and aquatic plants with the structure of phytoplankton and zooplankton communities. Freshwater Biology, 36: 315-325.

BERGSTRÖM, S. E., J. E. SVENSSON \& G. E. WESTBER. 2000. Habitat distribution of zooplankton in relation to macrophytes in a eutrophic lake. Verh. Internat. Verein. Limnol., 27: 2861-2864.

CARAMUJO, M. J., M. C. CRISPIM \& M. J. BOAVIDA. 1997. Assessment of the importance of fish predation versus copepod predation on life history traits of Daphnia hyalina. Hydrobiologia, 360: 243-252.

DUSSART, B. 1969. Les copepodes des eaux continentales d'Europe Occidentale - Tome II Cyclopoïdes et biologie, $1^{\text {st }}$ ed. Paris: Editions N. Boubée.

FORMIGO, N. 1990. Ictiofauna. In: Caracterização ecológica da albufeira do Azibo, com vista à 
determinação das suas potencialidades no domínio dos recursos vivos. IZAN (ed.): 143-169. Acções Preparatórias do Programa Integrado de Desenvolvimento Regional de Trás-os-Montes, Porto.

GASITH, A. \& M. V. HOYER. 1998. Structuring role of macrophytes in lakes: Changing influence along lake size and depth gradients. In: The structuring role of submerged macrophytes in Lakes. E. Jeppesen, M. Søndergaard, M. Søndergaard \& K. Christoffersen (eds.): 381-392. Springer, New York.

GERALDES, A. M. \&. M. J. BOAVIDA. 2003. Distinct age and landscape influence on two reservoirs under the same climate. Hydrobiologia, 504: 277-288.

GERALDES, A. M. \&. M. J. BOAVIDA. 2004. What factors influence the cladoceran assemblage of a meso-eutrophic reservoir? Annales de Limnologie, 40: 101-111.

GLIWICZ, Z. M. \& A. RYKOWSKA. 1992. 'Shore avoidance' in zooplankton: A predator-induced behavior or predator-induced mortality? Journal of Plankton Research, 14: 1131-1342.

HUNT, B. P. \& W. F. CARBINE. 1951. Food of young pike, Esox lucius L. and associated fishes in Peterson's ditches Houghton Lake Michigan. Trans. Amer. Fish. Soc., 80: 67-83.

JEPPESEN, E., T. LAURIDSEN, T. KAIRESALO \& M. R. PERROW. 1998. Impact of submerged macrophytes on fish-zooplankton interactions in lakes. In: The structuring role of submerged macrophytes in Lakes. E. Jeppesen, M. Søndergaard, M., Søndergaard \& K. Christoffersen (eds.): 91-114. Springer, New York.

KAIRESALO, T., I. TÁTRAI \& E. LUOKKANEN. 1998. Impacts of waterweed (Elodea canadensis Michx) on fish-plankton interactions in the lake littoral. Verh. Internat.Verein. Limnol., 26:18461851.

LAMMENS, E. H. R. R. \& W. HOOGENBOEZEM. 1992. Diet and feeding behaviour. In: Cyprinid fishes, systematics, biology and exploitation, I. J. Winfield \& J. S. Nelson (eds.): 352-376. Chapman \& Hall, London.

LAMPERT, W. \& U. SOMMER. 1997. Limnoecology - the ecology of lakes and streams. $1^{\text {st }}$ ed. Oxford University Press, New York.

LAURIDSEN, T., E. JEPPESEN, E. LANDKILDEHUS \& M. SØNDERGAARD. 2001. Horizontal distribution of cladocerans in arctic Greenland lakes- impact of macrophytes and fish. Hydrobiologia, 442: 107-116.

MURPHY, J. \& J. P. RILEY. 1962. A modified single solution method for the determination of phosphate in natural waters. Anal. Chim. Acta, 27: 31-36.

NURMINEN, L. K. L. \& J. A. HORPPILA. 2002. A diurnal study on the distribution of filter feeding zooplankton: Effect of emergent macrophytes, $\mathrm{pH}$ and lake trophy. Aquat. Sci., 64: 198-206.

SCOURFIELD, I. S. O. \& J. P. HARDING. 1966. A key to British freshwater Cladocera. Ambleside: Freshwater Biological Association.

VISMAN, V., D. J. MCQUENN \& E. DEMERS. 1994. Zooplankton spatial patterns in two lakes with contrasting fish community structure. Hydrobiologia, 284: 177-191.

WETZEL, R. G. 1990. Reservoir Ecosystems: Conclusions and speculations. In: Reservoir Limnology: Ecological Perspectives. K. W. Thornton, B. L. Kimmel \& F. E. Payne. (eds.): 227-238.Wiley Inter-Science, New York.

WETZEL, R. G. 2001. Limnology - Lake and River Ecosystems, $3^{\text {rd }}$ ed. New York: Academic Press.

WICKHAM, S. A. 1995. Cyclops predation on ciliates: Species-specific differences and functional responses. Journal of Plankton Research, 17: 1633-1646.

WINFIELD, I. J. \& C. R. TOWNSEND. 1992. The role of cyprinids in ecosystems. In: Cyprinid fishes, systematics, biology and exploitation, I. J. Winfield (ed.): 552-567. Chapman \& Hall, London. 
